\title{
Factors determining the stability, size distribution, and cellular accumulation of small, monodisperse chitosan nanoparticles as candidate vectors for anticancer drug delivery: application to the passive encapsulation of $\left[{ }^{14} \mathrm{C}\right]$-doxorubicin [Corrigendum]
}

Masarudin MJ, Cutts SM, Evison BJ et al. Nanotechnol Sci

Appl. 2015;8:67-80

The authors advise that Professor Geoffrey A Pietersz was erroneously omitted from the original author and affiliation list, the list should have been:

Mas Jaffri Masarudin ${ }^{1}$

Suzanne M Cutts ${ }^{2}$

Geoffrey A Pietersz ${ }^{3}$

Benny J Evison ${ }^{4}$

Don R Phillips ${ }^{2}$

Paul J Pigram ${ }^{5}$

${ }^{1}$ Department of Cell and Molecular Biology, Faculty of Biotechnology and Biomolecular Sciences, Universiti Putra Malaysia, Serdang, Malaysia; ${ }^{2}$ Department of Biochemistry, La Trobe University, Melbourne, Victoria, Australia; ${ }^{3}$ Bioorganic and Medicinal Chemistry Laboratory, Centre for Biomedical Research, Burnet Institute, Melbourne, Victoria, Australia; ${ }^{4}$ Department of Chemical Biology and Therapeutics, St Jude Children's Hospital, Memphis, TN, USA; ${ }^{5}$ Department of Physics, La Trobe University, Melbourne, Victoria, Australia

The Acknowledgment section should have contained the statement: This work was also supported by a research grant from Cancer Council Victoria.

\section{Publish your work in this journal}

Nanotechnology, Science and Applications is an international, peer-reviewed, open access journal that focuses on the science of nanotechnology in a wide range of industrial and academic applications. It is characterized by the rapid reporting across all sectors, including engineering, optics, bio-medicine, cosmetics, textiles, resource sustainability and science. Applied research into nano-materials, particles, nano-structures and fabrication, diagnostics and analytics, drug delivery and toxicology constitute the primary direction of the journal. The manuscript management system is completely online and includes a very quick and fair peer-review system, which is all easy to use. Visit http://www.dovepress.com/ testimonials.php to read real quotes from published authors. 